\title{
外乱を受ける係留船舶の挙動と索張力の関係について
}

\author{
井関 俊夫* ・大津 皓平* \\ 水野 弘之**.玉井 勝也**
}

\section{A Study on the Relationship between Mooring Forces and Ship Motions in Rough Condition}

\author{
Toshio ISEKI, Kohei OHTSU, \\ Hiroyuki MIZUNO and Katsuya TAMAI
}

\begin{abstract}
The forces in the mooring cables and displacement of ship motions were measured in order to analyze the relationship between themselves. The ship is a berthed LNG carrier with $270 \mathrm{~m}$ length. Results of this kind of measurement for the large ships have never been reported.

AR modelling procedure was taken for the spectral analysis and power spectra of fluctuating tension in the mooring cables were examined in detail. And, applying the power contribution analysis, the effects of ship motions upon the power spectrum of fluctuating tension were investigated. Furthermore, a computer simulation program for a moored ship was developed and applied to this measurement in order to examine the reliability of itself.
\end{abstract}

In this paper, the outline of these analysis are described and a few problems are discussed.

\section{1. 緒言}

荷役作業中の船舶は複数の係留索とフェンダーによって岸壁に固定されているが、その係留索の張り方 は荷役による喫水の変化や潮汐による水位の変化に応じ、各張力が常時適切な範囲内に収まるように留意 されなければならない。しかしながら、近年、外洋に面した海域に港湾が建設されるようになり、船舶の 大型化も相まって、激しい自然環境に基づく過大な外力、即ち冬季の風や波浪によって荷役作業に支障を 来たしたり係留索の切断事故等を起こすケースが増えている。このような問題を解決するために、理論計 算に基づくシミュレーション計算法 ${ }^{(1) ~(4)}$ が幾つか開発され、その手法を用いた総合的な係留問題の研究が 現在精力的に進められている(5)。

ところで、実船の係留索に働く張力を測定することは困難な場合が多く、実際に計測・解析された例 ${ }^{(6)}$ は 非常に少ない。したがって、上述のシミュレーション計算法の検証は模型実験によってなされているもの がほとんどであり、Lppが $200 \mathrm{~m}$ を越えるような大型船の係留問題については、寸法比から来る模型材質等 の問題により、その適用に扔いて若干の検討の余地が残されていると思われる。

そこで本研究では、大型係留船舶の動摇とその係留索の張力の関係を明らかにするために、実際に稼働 中のLpp $=270 \mathrm{~m}$ DLNG船を供試船として、船体の動摇量と係留索の変動張力の現地計測を行った。得られ た時系列に対してARモデルを用いたスペクトラム解析を行い、係留索の変動張力のパワースペクトラムを 詳細に検討した。さらに、多次元ARモデルを用いたパワー寄与率を計算することにより、船体の動摇量が 係留索張力に与える影響の解析を試みた。また、係留船舶の動摇シミュレーションプログラムむあわせて

* 正会員 東京商船大学（テ135-8533 東京都江東区越中島2-1-6)

**正会員 (侏エム・オー・マリンコンサルティング（テ108-0022 東京都港区海岸3-18-1） 
作成し、シミュレーション計算によってどの程度実 際の現象を再現できるのかを検討した。本報では、 解析の結果得られた若干の知見と問題点について報 告する。

\section{2. 計測の概要}

計測は平成 9 年 2 月 16 日から 17 日にかけて、 A港のLNGバースにおいて荷役前のアームクールダ ウン中と荷役終了後の 2 回にわけて行われた。供試 船B丸は $125,000 \mathrm{~m}^{3}$ 型LNG運搬船であり、供試船の船 体主要目ならびに計測時の喫水等は表 1 に示すとお りである。計測時の気象海象条件は表 2 に示すよう に、南西〜西南西の風が観測されていたが、風浪が 発達する風向ではなかったために港内の平均波高は $27 \mathrm{~cm}$ と低いむのであった。供試船は24本の係留索と 7つの係留ドルフィンによって栈橋に繋がれており、 それぞれの係留索の配置は図 1 に示すとおりであっ た。

A 港LNGバースでは各係留ドルフィン上にクイッ クリリース付きテンションメータが設置されており、 このクイックリリースに繋がれた各係留索の張力は 電気信号に変換され、栈橋上監視室内のファクトリ ーコンピュータに集められるようになっている。フ アクトリーコンピュータの画面上では各係留索の張 力変動を常時監視することができ、そのデータは 30 秒毎にハードディスクに記録されるようになってい る。今回の計測では供試船 B丸を繋いでいる24本の 係留索すべての張力を記録した。

船体動摇の計測は船橋に設置された動摇監視装置 (TOKIMEC : SMM-100) と栈橋からのビデオ撮影に よって行った。しかしながら、前述のように計測時 の港内波高は非常に小さく、変動風のみが船体動摇の起振力であったために船体動摇は微小振幅かつ長周 期となり、動摇監視装置の計測分解能を下回ってしまい、有効なデータを得ることはできなかった。一方、 ビデオカメラによる船体動摇の撮影・計測は、図 2 に示すように、一定間隔でマス目を描いたマグネット 付きリノリウム製計測板を船体側面に貼り付け、栈橋からプレゼンテーション用レーザーポインタを用い てレーザー光を計測板に照射し、船体動摇によって相対的に計測板上を移動する輝点を撮影することによ って行った。したがって、船体動摇量は撮影された輝点の上下左右の移動量で計測されるが、今回の港内 波高では船体上下動は起こりにくいと考えられるので、このビデオ撮影によって船体の前後動と横摇れが 計測されているものと思われる。

風向・風速の計測は供試船船橋および栈橋監視室において行った。供試船船橋では本船装備の風向風速 計を用いて 30 秒毎に記録し、栈橋監視室においてはターミナル本館屋上設置の風向風速計および栈橋設置 の風向風速計を用いて記録した。また、栈橋に設置してある波高計からのデータも同時に記録した。

\section{3. シミュレーションプログラムの概要}

計測された係留索張力の変動と船体動摇の相関を調べるにあたり、コンピュータによってどの程度実際 


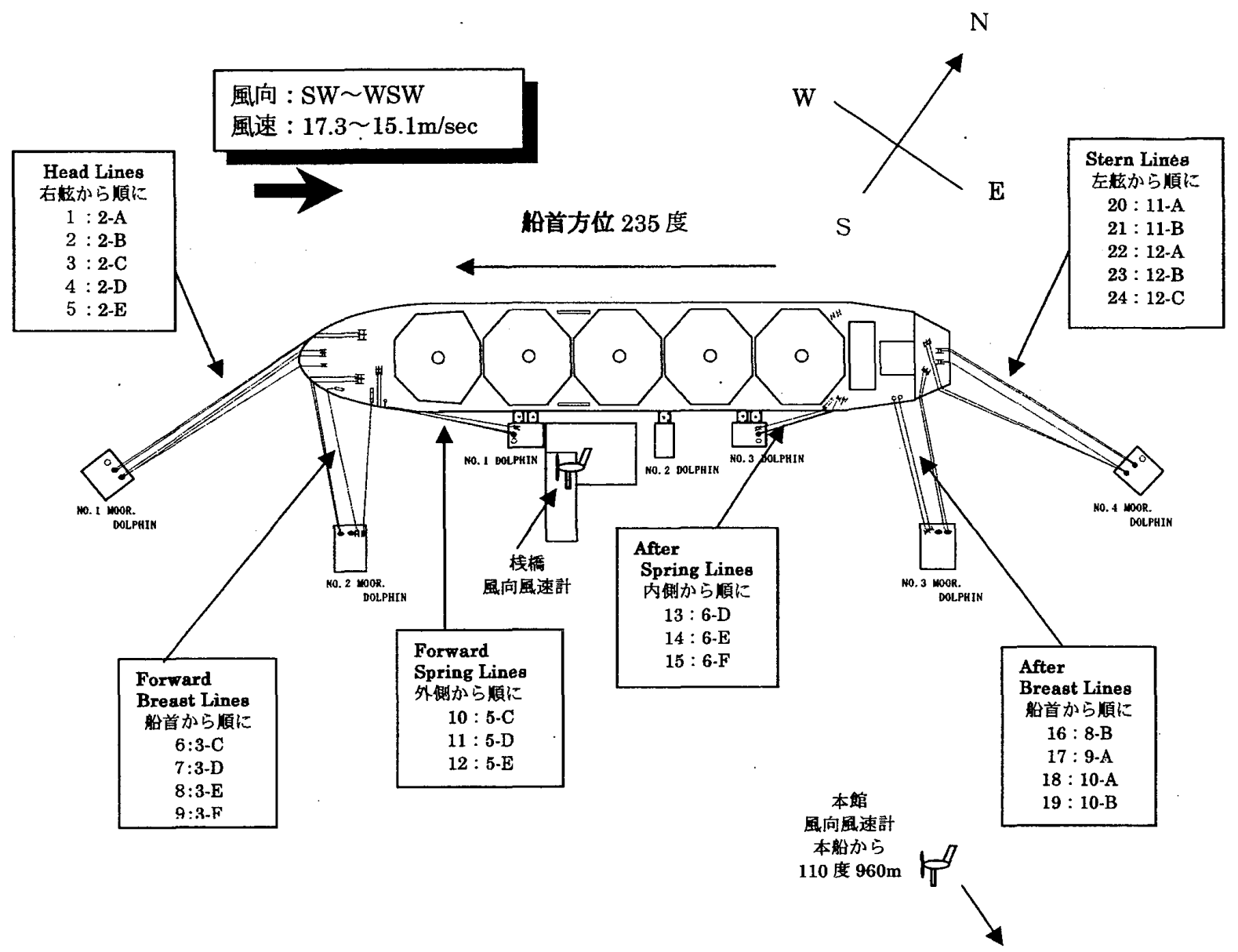

図 1 係留索配置と相対風向

の現象を再現できるのかを検討するために、係留船 舶の動摇シミュレーションプログラムを作成し、計 測結果との比較を行った。係留船舶の動摇シミュレ ーション法については多くの論文が出されており、 計算アルゴリズムの骨格部分は既に確立されている と思われるので、ここでは今回作成したシミュレー ションプログラムの概要と、他の論文の計算アルジ リズムと異なる点についてだけ述べる。

通常、係留船舶の動摇シミュレーションプログラ ムは大きく分けて2つの部分から構成される。第1は strip法等を用いて船体に加わる流体力を計算する部 分であり、第2は係留系を含んだ船体運動方程式を時 間積分して時々刻々の船体動摇量や係留索張力を求 める部分である。

第 1 の流体力計算は、時々刻々のシミュレーショ ン計算に先立って行われるデータベース作成作業を 意味し、計算対象の係留船舶が遭遇しうるあらゆる 出会い角・あらゆる周波数の波について波浪強制力 やラディエーション流体力を求めておくものである。 本計算では、船体各断面の 2 次元流体力を船長方向に

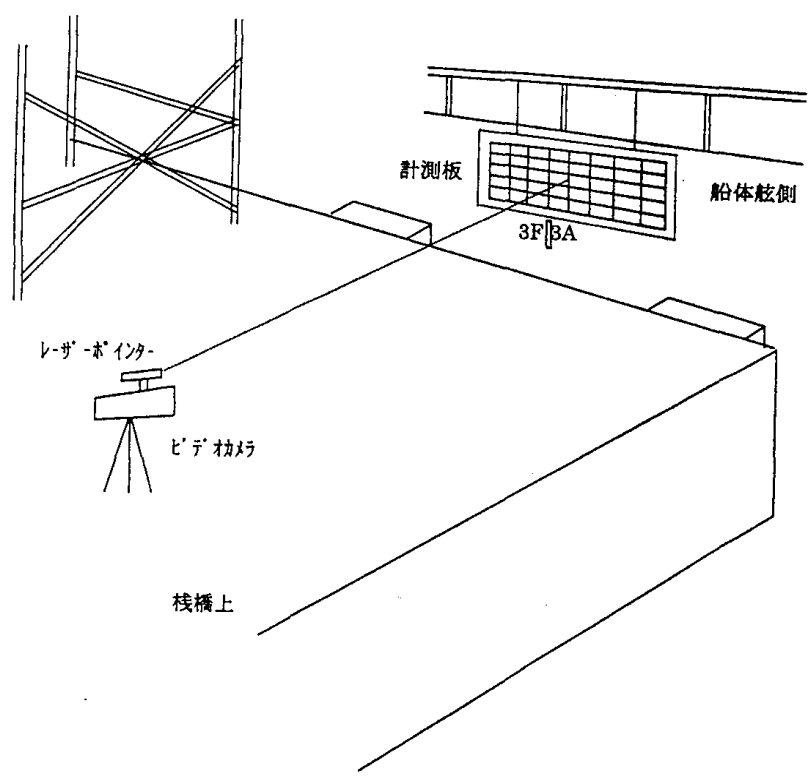

図 2 栈橋からのビデオカメラによる船体運動計 測状況 
積分して全体の流体力を求めるstrip法の一種であるNSM(New Strip Method) (7)を用いている。一般に港 湾内の係留船舶を取り扱う場合、流体力学的現象は浅水問題として捉える必要があるが、本プログラムの 2 次元流体力計算ではこの水深影響を考慮するために有限水深のGreen関数 ${ }^{(8)}$ を用い、船体形状を正確に考 慮するためのClose-Fit法 ${ }^{(9)}$ を併用している。ただし、このClose-Fit法にお抢る計算ではIrregular frequencyを避ける(10)ために境界要素法の直接法によって速度ポテンシャルを解く方法をとっている。また、定常 波漂流力は船体各断面のコチン関数を用いたFaltinsenの計算式(11)を用いている。

シミュレーションプログラムの第2の部分、すなわち係留系を含んだ船体運動方程式の時間積分では、ま ずDavenportの変動風スペクトラムとISSCの波スペクトラムを用いて不規則変動風と不規則波浪の 2 つの 外力の時系列を発生させ、これらの外力を船体運動方程式の右辺として、Wilson- $\theta^{(12)}$ 法によって時々刻々 時間積分する手法をとっている。ここで、運動方程式の係数は簡単のためConstant Coefficient法 ${ }^{(13)}$ を採 用しており、変動波漂流力の計算はHsuの方法 ${ }^{(14)}$ を採用している。

本動摇シミュレーションプログラムの特徵としては、上述の船体運動方程式の時間積分を始める前に係 留系の力学的釣り合いの状態を正確に求めている点にある。一般に、ヘッドライン、ブレストライン、ス プリングライン等はそれぞれ複数の係留索から構成されており、それぞれの係留索には数卜ンから数十卜 ンの初期張力がかけられている。これらの初期張力を同種の係留索の中で統一することは実際上困難であ り、通常、数トンから10数トンのばらつきがあるのが実状のようである。鋼製ワイヤーロープとナイロン 製テールロープで構成される大型船の係留索では、バネ定数は強い非線形性を示すとともに、その係留索 の繰出し量によってもバネ定数は異なったものとなる。したがって、係留索の破断等の極限状態をシミュ レートする場合には各係留索の初期張力を正しく考慮する必要があると予想される。このような理由によ り、本動摇シミュレーションプログラムでは初期張力を正しく計算に取り込むようにしている。

\section{4. 解析結果および考察}

ここでは、今回計測された係留索張力の時系列データに対してARモデルを用いたスペクトラム解析 ${ }^{(15)}$ 行い、各係留索の特徴や平均張力の差がパワースペクトラムに与える影響について調べた結果を示す。さ らに、係留索張力と船体動摇の時系列データに対して多次元ARモデルを用いたパワー寄与率の解析を行い、 係留索張力と船体動摇の相関を調べを結果を示す。

4.1 ARモデルを用いたスペクトラム解析結果

図 3 に計測された係留索張力の時系列の一例を示す。図は4本のアフターブレストラインの張力の計測結 果であり、サンブリング周期30秒で30分間計測したデータを滑らかに結んだものである。この図から各係 留索の張力の時系列はほぼ同じ波形を有しているものの、平均張力では10トン以上の差があり、かなりば らついていることが良くわかる。また、大型船の場合の初期張力はかなり大きな值をとっていることがわ かる。ここで、この計測結果は30秒といら比較的長いサンプリング周期をとっているため、実際の変動張 力の波形はさらに短い周期の成分を含んでいると考えられ、スペクトラム解析を行った場合エイリアシン グを起こす可能性が十分考えられる。したがって、

以下のスペクトラム解析の結果では単独のパワース ペクトラムから有意な結論を導き出すことを避け、 スペクトラム同士の比較から、周波数特性ならびに スペクトラムのパワーに関する結論を導き出すこと に重点を置くことにする。

図 4 (a)から図 4 (f)に、ヘッドライン、フォワード ブレストライン、フォワードスプリングライン、ア フタースプリングライン、アフターブレストライン およびスターンラインの変動張力のパワースペクト ラムを示す。それぞれの図にはほぼ同位置に取り付 けられた複数の係留索の変動張力のパワースペクト ラムが重ねて示してある(図 1参照)。これらの図か

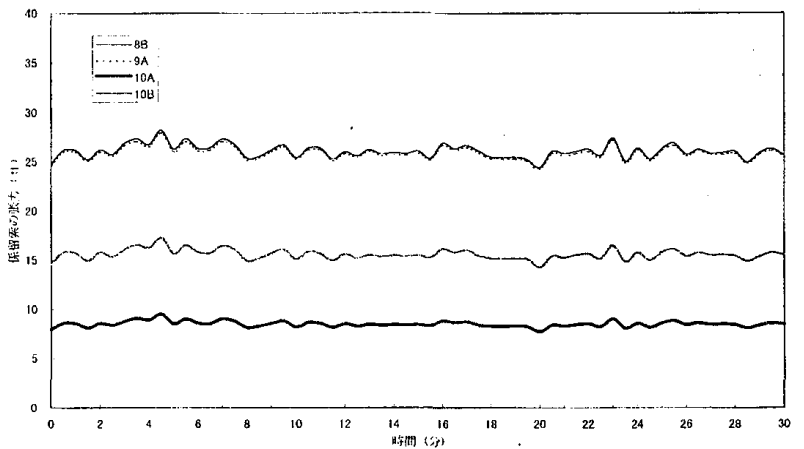

図 3 係留索張力の時系列の一例 (After Breast Lines) 


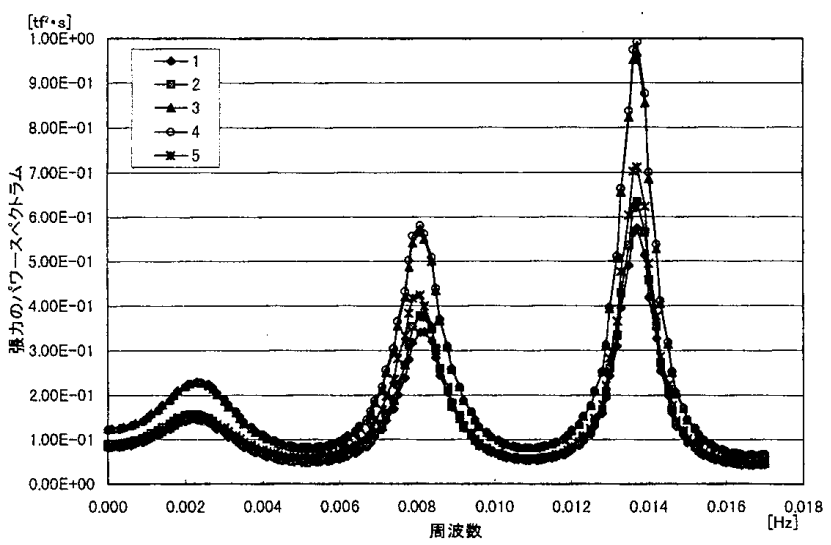

図 4（a） 変動張力のパワースペクトラム (Head Lines)

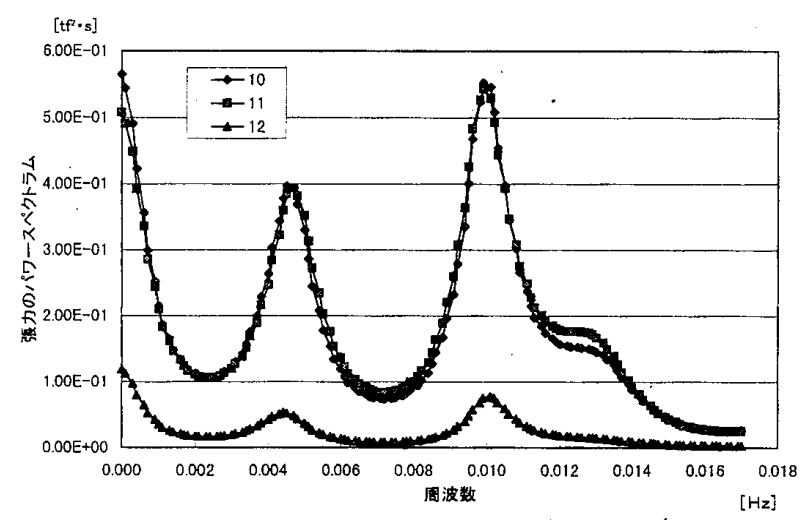

図 4(c) 変動張力のパワースペクトラム (Forward Spring Lines)

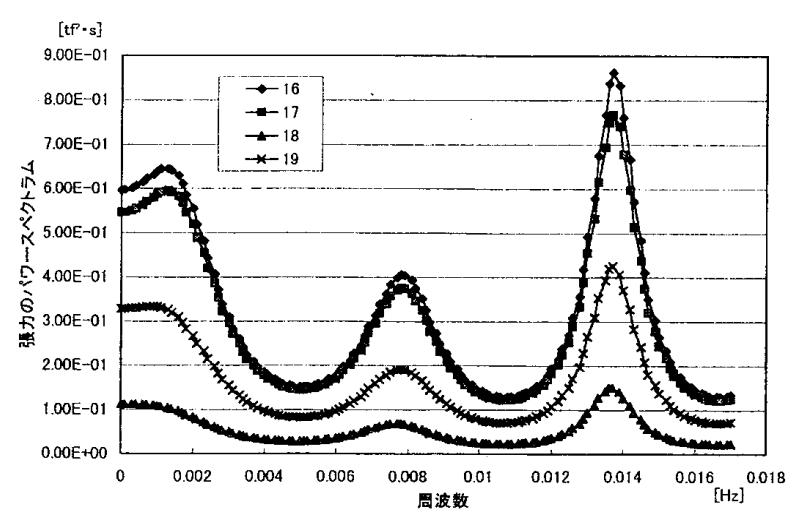

図 4(e ) 変動張力のパワースペクトラム (After Breast Lines)

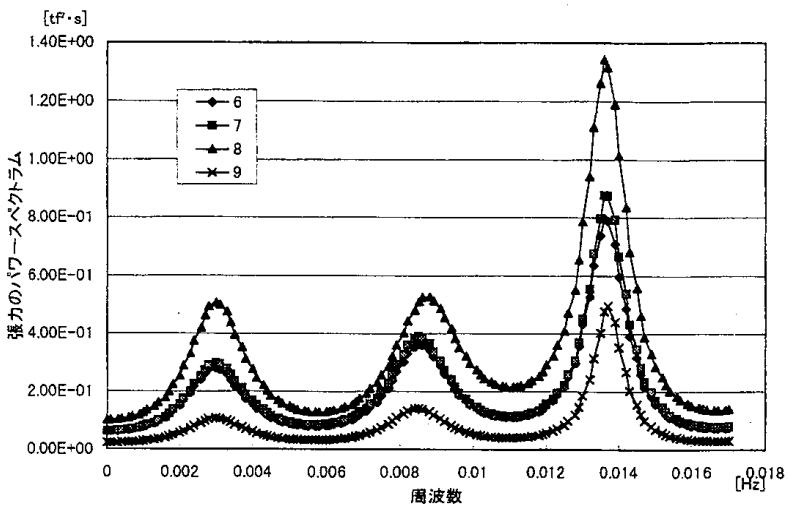

図 4(b) 変動張力のパワースペクトラム (Forward Breast Lines)

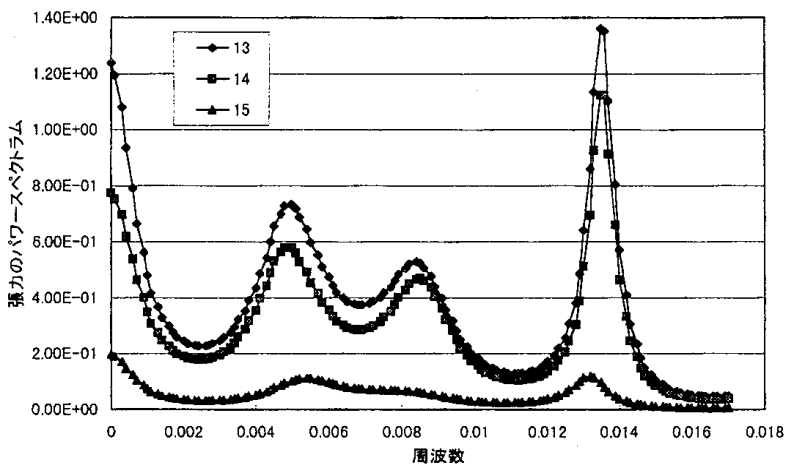

図 4 (d) 変動張力のパワースペクトラム (After Spring Lines)

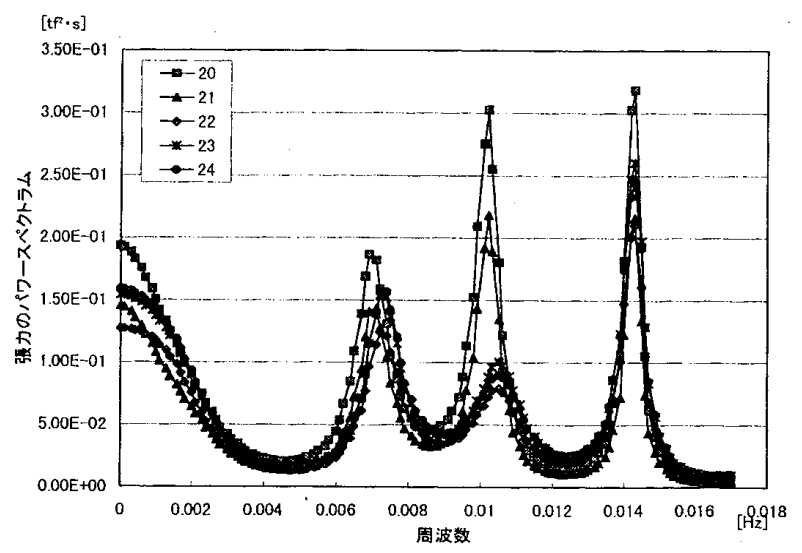

図 4 ( f ) 変動張力のパワースペクトラム (Stern Lines)

らわかるように、それぞれの変動張力のパワースペクトラムは複数のピークを持っており、その外形は同 一種類の係留索でほぼ一致している。しかしながら、それぞれのスペクトラムの面積には大きな差があり、 スペクトラムの面積が時系列の分散に等しいことを考慮すれば、各係留索の変動張力の有義值を検討する 場合には注意が必要であることがわかる。また、図 4 (a)から図 4 (f) のスペクトラムのピーク位置を比較し てみると、係留索の取り方によってスペクトラムのピーク位置が異なることがわかる。特にこれらのスペ 


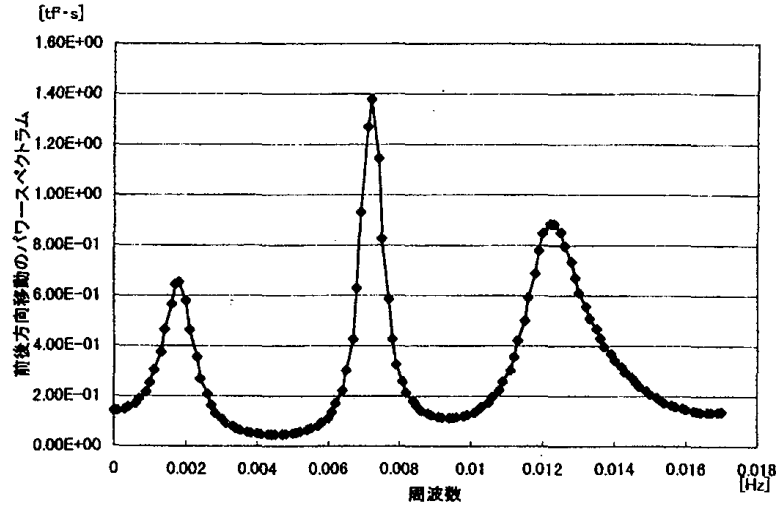

図 5 (a) 船体前後方向移動量のパワースペクト ラム

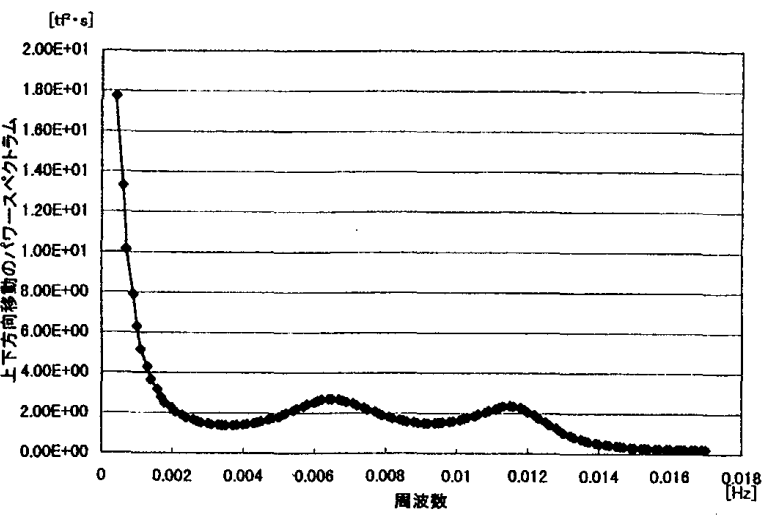

図 5 （b）船体上下方向移動量のパワースペクト ラム

クトラムの中でフォワードスプリングラインとスターンラインのスペクトラムは $0.01 \mathrm{~Hz}$ 付近にピークを持 っており、他の係留索のスペクトラムと違った傾向が見受けられる。これらのピーク位置が一致しない理 由としては、それぞれの係留索が6自由度の船体運動の中のどの運動にもっとも強く影響を受けるかという ことが大きく関係しているものと思われる。

図 5 (a) と図 5 (b)には、ビデオで撮影された船体動摇の前後方向移動量のスペクトラムと上下方向移動 量(横摇れ)のスペクトラムを示す。これらの図から、船体動摇のスペクトラムも係留索張力のスペクトラ ムと同様に複数のピークを持つことがわかる。また、これらの船体動摇のスペクトラムのピーク位置と係 留索張力のスペクトラムのピーク位置の比較から、船体動摇がどの係留索の張力に影響を与えているかを ある程度推定することができる。

\section{2 多次元ARモデルを用いた解析結果}

係留索張力と船体動摇の相関を調べるために、多次元ARモデルを用いてパワー寄与率 ${ }^{(15)}$ の解析を行った。 図 6 (a)から図 6 ( c ) には、係留索の変動張力に対する船体前後方向ならびに上下方向の移動量のパワ一寄 与率を示している。それぞれのグラフには"Noise from itself"、“x-displacement"および"y-displacement" の3つの領域が示されており、それらの領域はそれぞれ当該係留索自身のノイズ、前後方向移動量からの パワーおよび上下方向移動量からのパワーを意味している。なお、それぞれの領域の区別がつきやすいよ

Head Line 2-D

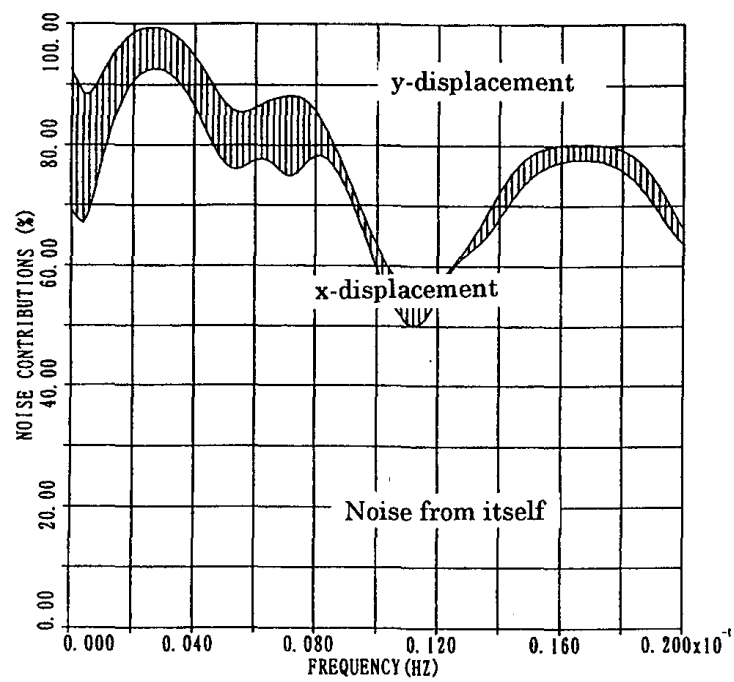

Forward Breast Line 3-E

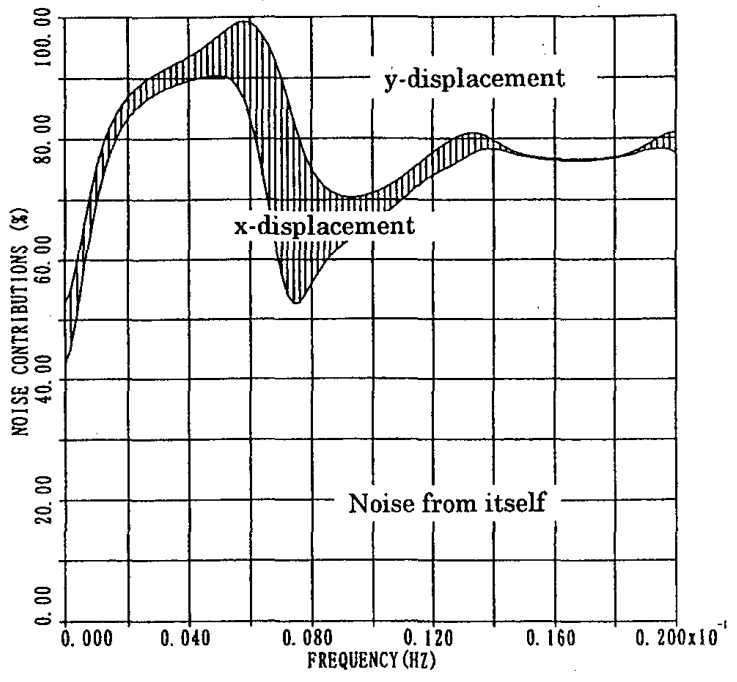

図 6 （a）＼cjkstart変動張力のスペクトラムに対するパワー寄与率 (Head Line \& Forward Breast Line ) 
After Spring Line 6-D

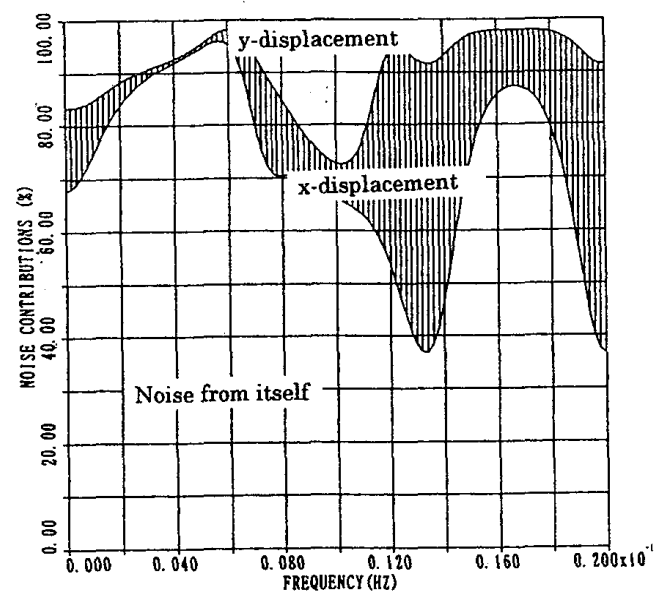

After Breast Line 8-B

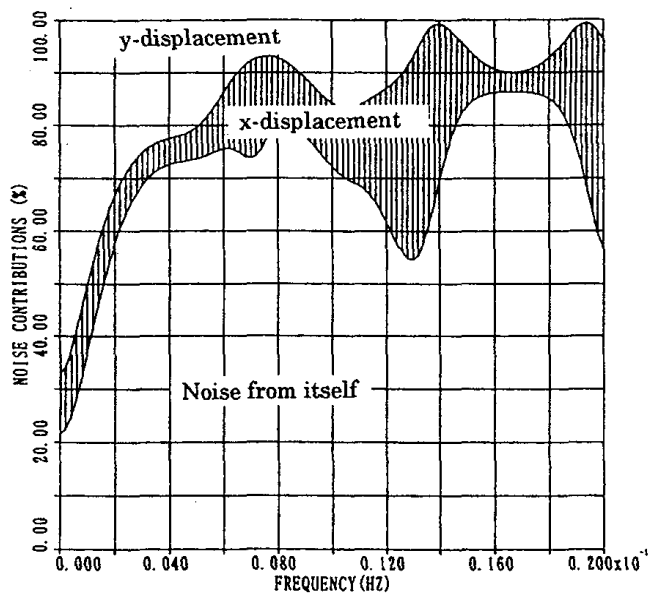

図 6 (b) 変動張力のスペクトラムに対するパワー寄与率 （After Spring Line \& After Breast Line）

Forward Spring Line 5-C

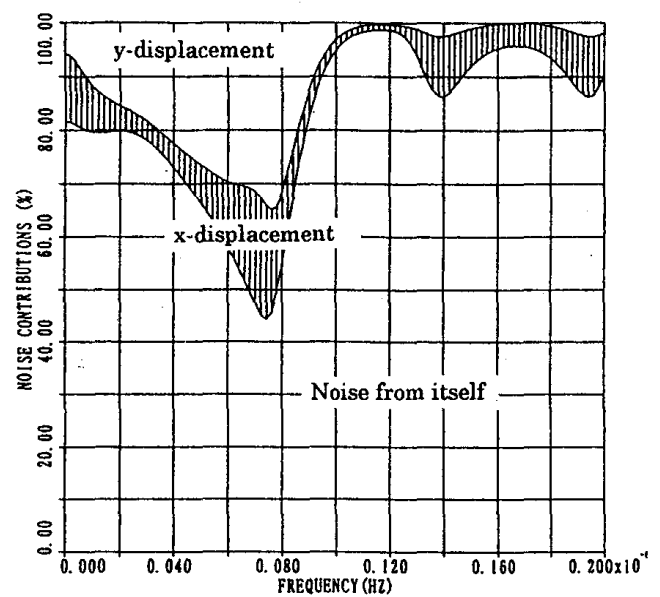

Stern Line 11-A

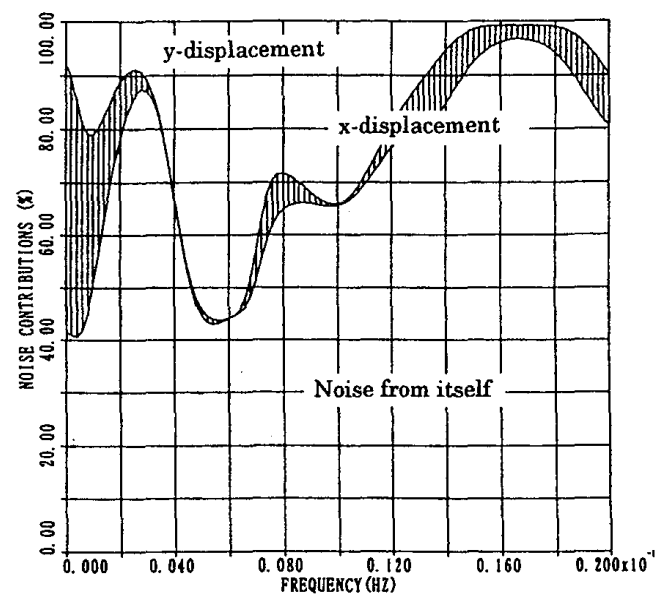

(Forward Spring Line \& Stern Line)

図 6 (c) 変動張力のスペクトラムに対するパワー寄与率

うに、前後方向移動量からのパワーのみにハッチングを施している。図からわかるように、6本の係留索 に対するパワー寄与率のパターンは大きく 3 つのグループに分けることができる。すなわち、1つめのグ ループはヘッドラインとフォワードブレストラインのグループであり、図 6 (a) に示されるように高周波側 での船体上下方向移動量 (y-displacement) の寄与率が他のグループに比べて有意な値をとる傾向を示して いる。2つめのグループはアフタースプリングラインとアフターブレストラインのグループであり、図 6 (b)のように高周波側で船体前後方向移動量 (x-displacement)の寄与率が他のグループと比べて大きな值を とる傾向を示している。最後のグループは、フォワードスプリングラインとスターンラインのグループで あり、前節のパワースペクトラムの比較において他の種類の係留索と違った傾向を示したものである。こ のグループの特徴は図 6 (c)に示されるように、0.06Hzを中心とした周波数帯で船体上下移動量 (y-displacement) の奇与が他のグループと比較して大きくなることである。以上のように、船体動摇が係留索の張力変動に 与える影響は単純に幾何学的・力学的に推定することは困難であり、周波数帯によって相関の度合いが異 なることが良く分かる。

\section{3 シミュレーション結果と害験結果との比較}

本研究で作成した係留船舶の動摇シミュレーションプログラムを用いて、実験状態とできるだけ近い条 件でシミュレーション計算を行った。図 7 は本プログラムによって発生させた変動張力の時系列をスペク トラム解析した結果であり、図 4 (a) と同様に5本のヘッドラインの変動張力のパワースペクトラムを表し ている。図 4 (a) と比較すると、0.03Hz付近のピークの現れかたや各パワースペクトラムの面積が係留索に 
よって異なる様子が良く再現されていることがわか

る。ほぼ同じ位置に張られた係留索であるにも拘ら ず、変動張力のパワースペクトラムの面積が異なる 原因はそれぞれの係留索の平均張力 (初期張力)の違 いに起因しており、その様子は図 8 (a)および図 8 (b) から容易に理解することができる。

図 8 (a)および図 8 (b) は各係留索の平均張力と変 動張力の有義值の相関を24本のすべての係留索につ いて調べたもので、図 8 (a) は赛験結果をもとにした 散布図であり、図 8 (b) はシミュレーション結果をも とにした散布図である。ここで、変動張力の有義値 とはスペクトラムの面積から計算された $1 / 3$ 最大平均 值を意味しており、スペクトラムの面積を $m_{0}$ とする と $4 \sqrt{m_{0}}$ で求められる量である。実験結果の図 8 (a) の散布図を見ると全体的に右上がりの傾向が見受け られ、係留索の平均張力が大きくなると変動張力の 有義值も増大することがわかる。すなわち、平均張 力が大きな係留索は張力の变動が大きく、過酷な気 象・海象条件の下では破断する可能性が高いことが 理解できる。図 8 (b)のシミュレーション結果は図 8 (a)の傾向を良く再現しており、本シミュレーション プログラムによる結果が変動張力の推定に対して有 用性のあることを示している。

\section{5. 結言}

本報告では、大型係留船舶の動摇とその係留索の 張力の関係を明らかにするために、 $\mathrm{Lpp}=270 \mathrm{~m}$ の実 船を供試船として、船体の動摇量と係留索の変動張 力の現地計測を行った。計測された時系列に対して ARモデルを用いたスペクトラム解析を行い、それぞ れの係留索について変動張力のパワースペクトラム を詳細に検討した。さらに、多次元ARモデルを用い たパワー寄与率を計算することにより、船体の動摇 量が係留索張力に与える影響を明らかにすることを 試みた。また、係留船舶の動摇シミュレーションプ ログラムを作成し、シミュレーション計算によってどの程度実際の現象を再現できるのかを検討した。得 られた結論をまとめると以下のようになる。

1. 係留索の変動張力の時系列をスペクトラム解析した結果、ヘッドライン、ブレストライン等の係留 索の種類によってスペクトラムのピーク位置が異なることがわかった。

2. 変動張力のスペクトラムピーク位置の比較、ならびにパワー寄与率の解析結果より、各係留索は幾 つかのグループに分けることができる。

3. 平均張力の大小は、変動張力スペクトラムのピーク位置に影響を与えないが、変動張力の有義值に 大きな影響を与える。

4. 係留船舶の動摇シミェレーション計算を行う場合には、各係留索の平均張力を正しく考慮する必要 がある。

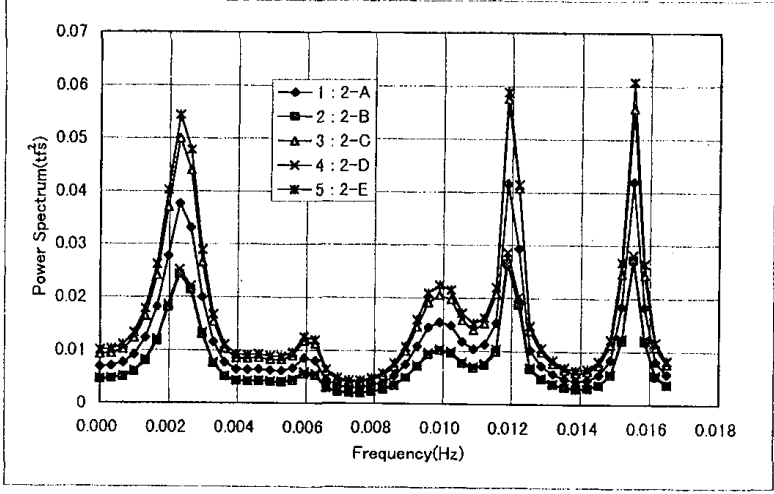

図 7 シミュレーションから得られた変動張力の パワースペクトラム (Head Lines)

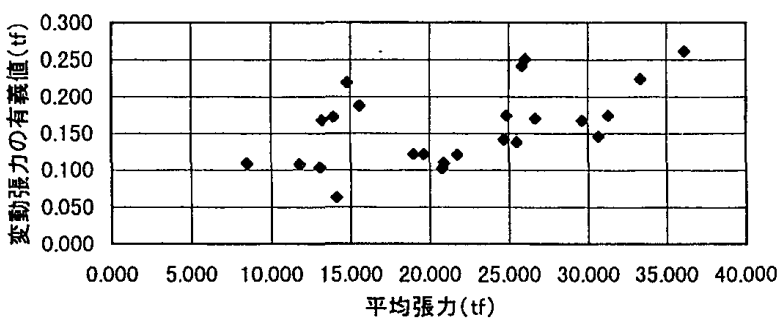

図 8 (a) 変動張力の有義值と平均張力の相関(実 験結果）

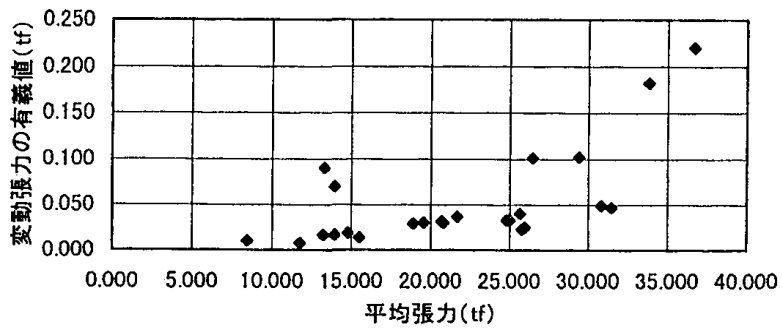

図 8（b） 変動張力の有義值と平均張力の相関 (シミュレーション効果) 


\section{謝 辞}

係留索張力の現地計測に際して、LNGターミナルならびに実験供試船関係各位から快いご承諾とご協力 を賜りました。心から感謝の意を表します。また、本論文の作成に当たりご協力下さいました織田美千子 さんに御礼申し上げます。

\section{参 考 文 献}

（1） 小林正典・島田 潔・藤平 徹：複合外力下における係留浮体の応答シミュレーションプログラム, 三井造船技報，第125号，pp.10-18，1985.

（2）久保雅義・斎藤勝彦：岸壁に任意の角度で係留された浮体式係船岸の動摇特性, 日本航海学会論文集, 第84号, pp.75-84, 1991.

（3）斎藤勝彦・J.M.A. Spencer・久保雅義：係留船の長周期動摇に関する数值シミュレーション，日本航 海学会論文集, 第93号, pp.131-139, 1995.

(4) R.Natarajan \& C.Ganapathy : Analysis of a Berthed Ship, Marine Structures 8, Elsevier Science LTD, 1995.

（5）久保雅義・津金正典・笹健 児・榊原繁樹 : 外洋に面した海域に立地する港湾の係留問題について, 日本航海学会論文集，第96号，pp.259-267，1997.

(6) 新井信一・高梨清一・平山 久: 岸壁係留時の挙動に関する実船実測, 海岸工学論文集, 第38巻, pp. 741-745, 1991.

（7）元良誠三監修：船体と海洋構造物の運動学, 成山堂, 1982.

（8）一色 浩・前田久明：周期的吹き出しの公式とその数值計算法, 関西造船協会誌, 第 157 号, pp.73-82, 1975.

（9）前田久明：任意船型におよぼす波の強制力について, 日本造船学会論文集, 第126号, pp.55-83, 1970.

(10) 別所正利・経塚雄策：水の波の理論における内部問題について, 西部造船会々報, 第 57 号, pp.37-52, 1978.

(11) Faltinsen, O.M., Michelson, F.C. : Motions of Large Structures in Waves at Zero Froude Number, International Symposium on the Dynamics of Marine Vehicles and Structures in Waves, pp.91-106, 1974.

(12) 戸川隼人：微分方程式の数值計算一有限要素法と差分法一, オーム社, 1973.

(13) 高木又男・斎藤公男・大久保寛・平島充男 : 非周期的造波問題の周波数領域での取り扱い(第6報), 関 西造船協会誌，第191号，pp.121-127，1984.

(14) Hsu, F.A., Blenkarn, K.A. : Analysis of Peak Mooring Forces by Slow Vessel Drift Oscillation in Random Seas, OTC paper No.1159, pp.1135-1146, 1970.

(15) 山内保文監修：船舶・海洋技術者のための不規則現象論, 海文堂, 1986.

\section{質 疑 応 答}

斎藤勝彦 (神戸商船大学)：上下変位量のスペクトラムをみると定常成分が卓越していますが、実験中の潮 汐、荷役による喫水変化の影響があるのですか。

井関俊夫：計測は荷役開始前と荷役終了後に行っていますので、計測中の喫水変化はありません。潮汐の 変化については詳しく計測しておりませんが、30分の計測中に風力が若干落ちてきておりましたので、 その影響が支配的ではないかと思います。

久保雅義 (神戸商船大学)：流体力係数を一定にすることは長周期波運動に大きな影響を与えるので注意す べきだと考えますが、いかがでしょうか。

井関俊夫：ご指摘のとおりだと思います。ただ、今回の計測ではほとんど船体動摇はありませんでしたの でシミュレーション結果に対するConstant Coefficient法の影響は小さいのではないかと思います。 